\title{
HEAVY METAL CONTAMINATION AND DISTRIBUTION IN THE URBAN ENVIRONMENT OF JELGAVA
}

\author{
Jovita Pilecka ${ }^{1}$, Inga Grinfelde ${ }^{1}$, Kristine Valujeva ${ }^{1}$, Inga Straupe ${ }^{1}$, Oskars Purmalis ${ }^{2}$ \\ ${ }^{1}$ Latvia University of Agriculture \\ ${ }^{2}$ University of Latvia \\ jovita.pilecka@1lu.lv
}

\begin{abstract}
The growing economy with following industrialization and urbanization has led to environmental contamination with trace elements worldwide. In urban environment, the large inputs of anthropogenic contaminants in atmosphere are arising from mobile and stationary sources. The snow sample analysis is one of methods to monitor air contamination with heavy metals in urban areas. The aim of this research is to analyse heavy metal contamination and distribution in urban environment of Jelgava city. The samples were collected twice in January and February. Snow samples were collected in 20 urban area sampling plots and one natural area sampling plot with three repetitions taken from 1.0 to $1.5 \mathrm{~kg}$ of snow. The concentration of trace elements was estimated in 126 melted and filtrated snow water using inductively coupled plasma spectrometer (ICP-OES). The average heavy metals and nutrients concentrations were calculated for each sample. The concentrations data of trace elements were analysed using agglomerative hierarchical clustering method.

The results show differences between results in January and February. The differences are related to anthropogenic impact intensity differences during the exposition periods of snow. The clustering results of snow samples taken in January show three clusters, but snow samples taken in February show four clusters.
\end{abstract}

Key words: ICP-AES; air quality; snow; pollution.

\section{Introduction}

The growing economic activity leads to more intensive exploitation of natural resources. The mining and industrial use of minerals as well as usage of different chemicals in agriculture and households lead to air pollution with trace elements (Tchounwou et al., 2014). The snow geochemistry has become a topic of interest since Antarctica, Greenland and Arctic snow and ice trace elements research results were published (Candelone et al., 1996; Gabrielli et al., 2005a; Barbante et al., 2011; Barbante et al., 2003; Shotyk et al., 2005). The anthropogenic impact on trace elements distribution are investigated in the Andes (Correia et al., 2003) and some studies have been done next to urbanised areas in the European Alps (Van de Velde et al., 2000; Schwikowski et al., 2004). Snow as an indicator for urban air pollution is used in several studies (Dossi et al., 2007; Engelhard et al., 2007).

Many of trace elements are hazardous (e.g. Cd, $\mathrm{Pb}, \mathrm{Ni}$ ) for human health and ecosystem (Wiener et al., 2003). The major trace elements are associated with both natural and industrial processes (Gabrielli et al., 2008). The sources of industrial air pollution trace elements are different: fossil and oil combustion (As, Cu, Co, Cr, V, Ni, Sb, Fe, Mn, Zn, Sn, Mn, Pb, $\mathrm{Fe}, \mathrm{Ni})$; waste water management $(\mathrm{Pb}, \mathrm{Zn})$; steel production $(\mathrm{Cr}, \mathrm{Mn}, \mathrm{Ni}, \mathrm{Co})$; transport emissions $(\mathrm{Pb}$, $\mathrm{Cu}, \mathrm{Cr}, \mathrm{Sn}, \mathrm{Sb}$ ) and others (Pacyna \& Pacyna, 2001). The concentrations of trace element in troposphere are with high temporal and spatial variability (Melaku et al., 2008). Snow samples with short exposition period are analysed in several studies. The trace elements from transport emissions in snow cover at roadsides and crossroads have been analysed (Loranger et al., 1996; Engelhard et al., 2007; Vasić et al., 2012). The significant anthropogenic emissions of trace elements related with industrial gases and energetic sector were found in long term trace element monitoring by Moreno et al. (2011).

The aim of this research is to analyse concentrations and distribution of trace elements in urban environment of Jelgava city. The objectives are (1) to analyze the composition of metal in snow in Jelgava city; (2) to analyze the distribution of metals in different places of Jelgava city and to conduct cluster analysis; (3) to compare the concentrations of metals in different places of Jelgava city taken in January and February.

\section{Materials and Methods}

\section{Study area}

Jelgava city has an area of $60.3 \mathrm{~km}^{2}$ and more than 57000 inhabitants. The climate in Jelgava is cold and temperate. The yearly average temperature is $6.5^{\circ} \mathrm{C}$ and average annual precipitation is $642 \mathrm{~mm}$. Snow cover is normally from November till March, and the length of snow exposition period is impacted by local meteorological conditions such as city heat island influence. The main wind direction is from southwest. The research area is an urban territory of Jelgava city with different urbanisation level. Sampling plots were chosen close to transport corridors, industrial areas and living areas. The additional spot Mežciems was chosen in forest area in south west direction from the city centre to identify transboundary air pollution with trace elements. The sampling plots description is presented in Table 1. 
Sampling plots coordinates and anthropogenic pressure

\begin{tabular}{|c|c|c|c|c|}
\hline No & Name of sampling point & $\mathrm{X}$ coordinate & Y coordinate & Characteristics of anthropogenic impact \\
\hline 1 & Viskaḷu str./Lietuvas str. & 483086.650 & 6275689.140 & Close to transit street and living area \\
\hline 2 & Platones str./Lietuvas str. & 482975.520 & 6276218.310 & Close to transit street and living area \\
\hline 3 & Savienības str./Lietuvas str. & 483293.026 & 6276805.680 & Close to transit street road and \\
\hline 4 & Train station & 483525.860 & 6277369.250 & Jelgava train station \\
\hline 5 & Tērvetes str./railway & 481838.609 & 6276571.000 & Transit street and railway \\
\hline 6 & Rūpniecības str./Tērvetes str. & 482043.660 & 6276941.400 & Transit street and gasoline station \\
\hline 7 & Tērvetes str./Pavasara str. & 482380.199 & 6277740.316 & Urban area with street canyon \\
\hline 8 & Lielā str./Kalpaka str. & 482241.609 & 6278438.223 & Open area close to mine street \\
\hline 9 & Lielā str./Dobeles str. & 481903.940 & 6278612.119 & Between two main streets \\
\hline 10 & Aspazijas str./Asteru str. & 481388.500 & 6278423.200 & Open area close to school \\
\hline 11 & Dobeles str./Satiksmes str. & 481436.100 & 6278707.899 & $\begin{array}{l}\text { Main street and car roadworthiness test } \\
\text { centre }\end{array}$ \\
\hline 12 & Satiksmes str./Ganību str. & 481507.072 & 6279135.466 & Main street and gasoline station \\
\hline 13 & Ausekḷa str./Blaumaṇa str. & 482801.400 & 6279119.060 & City market and intensive traffic \\
\hline 14 & Pasta island & 483563.400 & 6278804.200 & Open are between rivers close to main street \\
\hline 15 & Rīgas str./Brīvības str. & 484290.526 & 6279236.721 & $\begin{array}{l}\text { Open are three main streets and gasoline } \\
\text { station }\end{array}$ \\
\hline 16 & Prohorova str./Neretas str. & 485513.400 & 6278465.500 & Industrial area \\
\hline 17 & Garozas str./Rubeņu str. & 485772.690 & 6278788.330 & Near to railway \\
\hline 18 & Aviācijas str./Lāčplēša str. & 485302.390 & 6279209.020 & Industrial area \\
\hline 19 & Rīgas str./Loka str. & 485437.330 & 6280722.440 & Intensive traffic gasoline station \\
\hline 20 & Institūta str./Rīgas str. & 484630.350 & 6279806.980 & Intensive traffic car parking area \\
\hline 21 & Mežciems & 486643.054 & 6277428.039 & Natural area \\
\hline
\end{tabular}

\section{Sampling strategy}

The samples were collected twice in January and February with snow exposition period 7 days. The snowing was on the second of January and seventh of February, and sampling was done on $10^{\text {th }}$ of January and $14^{\text {th }}$ of February. Three snow samples were collected during each sampling period in each sampling plot. Plastic bags and gloves were used to avoid negative artefacts during snow sampling. The snow cover was collected via the use of a pre-cleaned Plexiglas device and a plate. Each snow column was taken from the whole depth of snow.

The concentration of trace elements was estimated in the 126 melted snow water and HNO3 solution samples using inductively coupled plasma spectroscopy (ICP-OES) method. The average concentrations of $\mathrm{Cd}, \mathrm{Cu}, \mathrm{Pb}, \mathrm{Ca}, \mathrm{Mg}, \mathrm{Na}, \mathrm{Fe}, \mathrm{Zn}$, $\mathrm{Ni}, \mathrm{Cr}, \mathrm{Mn}, \mathrm{K}, \mathrm{As}, \mathrm{Co}, \mathrm{Li}, \mathrm{Sr}, \mathrm{Ti}, \mathrm{Tl}, \mathrm{Ba}, \mathrm{V}, \mathrm{Al}, \mathrm{P}$ and $\mathrm{Sb}$ were calculated for each sample. The sampling plot average concentrations standardised values for January and February concentrations data were analysed using agglomerative hierarchical clustering method.

\section{Results and Discussion}

Snow samples were collected in January and content of 26 trace elements have been analysed using ICP-OES. The concentrations of $\mathrm{Cu}, \mathrm{Pb}, \mathrm{Ca}, \mathrm{Mg}$, $\mathrm{Na}, \mathrm{Fe}, \mathrm{Zn}, \mathrm{Ni}, \mathrm{Cr}, \mathrm{Mn}, \mathrm{K}, \mathrm{Co}, \mathrm{Li}, \mathrm{Sr}, \mathrm{Ti}, \mathrm{Ba}, \mathrm{Al}, \mathrm{P}$ were different between samples and other elements concentrations were smaller than instrument error, and they were excluded from further analysis. Snow samples taken in January, average trace elements concentration data cluster dendogram is presented in Figure 1.

There are three separate clusters with different trace element concentrations. The first cluster represents areas close to main streets with intensive traffic. The concentrations of $\mathrm{Cu}, \mathrm{Pb}, \mathrm{Fe}, \mathrm{Zn}, \mathrm{Ni}, \mathrm{Cr}, \mathrm{Mn}, \mathrm{Co}$, $\mathrm{Li}, \mathrm{Ti}, \mathrm{Ba}, \mathrm{Al}, \mathrm{P}$ are low and close to natural sample concentrations, see Table 2 . The concentrations of $\mathrm{Ca}$ $\left(4.5 \pm 2.31 \mathrm{mg} \mathrm{L}^{-1}\right) ; \mathrm{Mg}\left(1.6 \pm 0.85 \mathrm{mg} \mathrm{L}^{-1}\right) ; \mathrm{Na}(13.0$ $\left.\pm 1.49 \mathrm{mg} \mathrm{L}^{-1}\right) ; \mathrm{K}\left(0.8 \pm 0.6 \mathrm{mg} \mathrm{L}^{-1}\right)$ and $\mathrm{Sr}(7.3 \pm$ $\left.2.3 \mu \mathrm{g} \mathrm{L}^{-1}\right)$ are higher than second and third cluster and significantly higher than that in pristine areas (Shevchenko, 2016). 


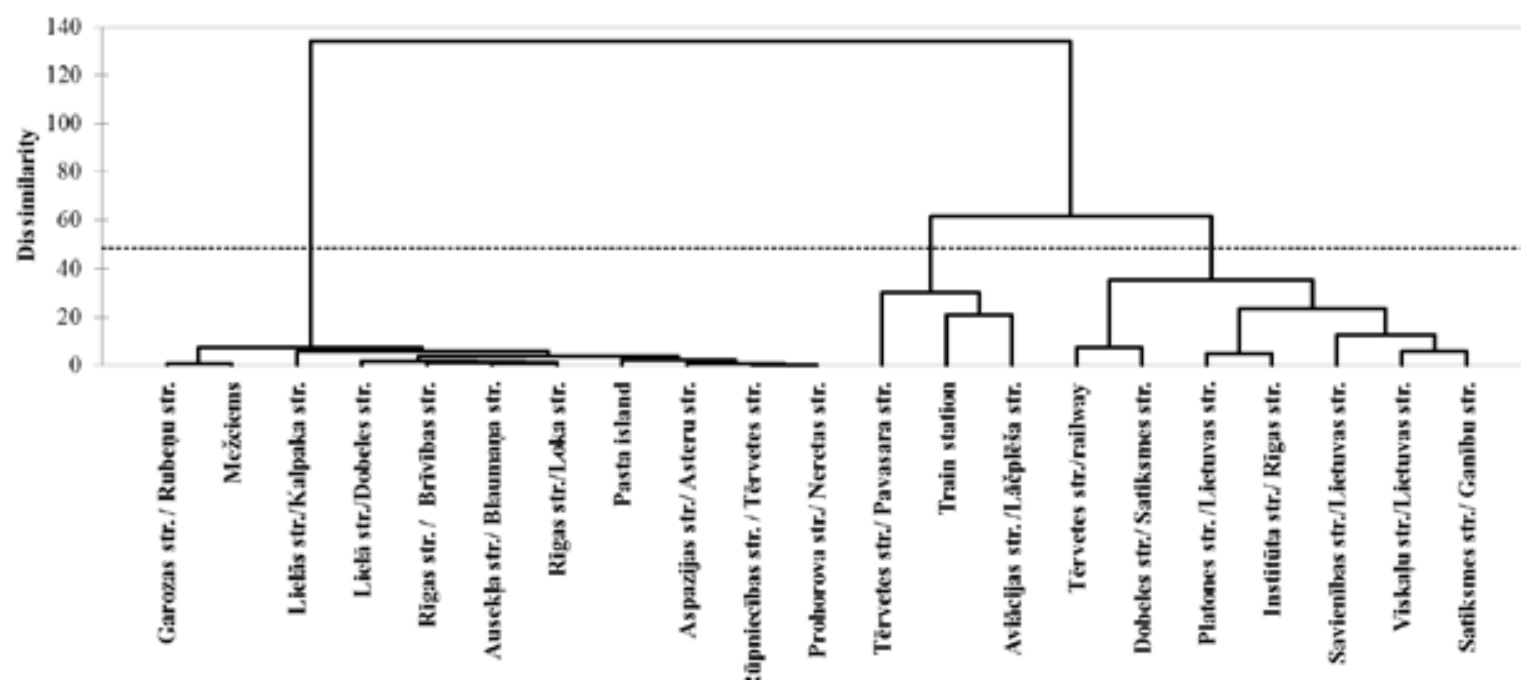

Figure 1. Dendogram of cluster analysis of snow samples taken in January.

Table 2

The mean ad standard deviation of trace elements by cluster for snow samples taken in January

\begin{tabular}{|c|c|c|c|c|c|c|c|c|c|c|}
\hline \multirow[b]{2}{*}{ 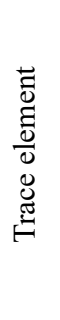 } & \multirow[b]{2}{*}{ 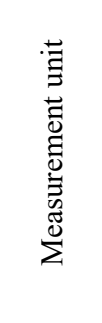 } & \multicolumn{3}{|c|}{$1^{\text {st }}$ cluster } & \multicolumn{3}{|c|}{$2^{\text {nd }}$ cluster } & \multicolumn{3}{|c|}{$3^{\text {rd }}$ cluster } \\
\hline & & 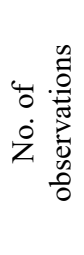 & $\stackrel{\Xi}{\stackrel{\Xi}{ٍ ల ~}}$ & 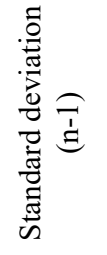 & 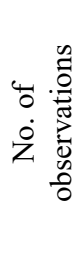 & $\sum_{\Sigma}^{\mathbb{E}}$ & 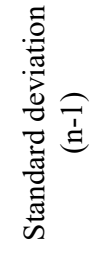 & 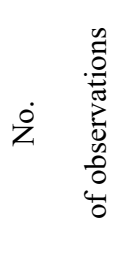 & $\stackrel{\Xi}{\Xi}^{\Xi}$ & 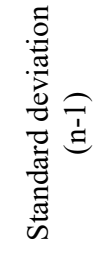 \\
\hline $\mathrm{Cu}$ & $\mu \mathrm{g} \mathrm{L}^{-1}$ & 21 & 3.3 & 0.834 & 9 & 28.7 & 4.220 & 33 & 2.4 & 0.791 \\
\hline $\mathrm{Pb}$ & $\mu \mathrm{g} \mathrm{L}^{-1}$ & 21 & 1.2 & 0.669 & 9 & 7.3 & 0.876 & 33 & 0.9 & 0.608 \\
\hline $\mathrm{Ca}$ & $\mathrm{mg} \mathrm{L}^{-1}$ & 21 & 4.5 & 2.314 & 9 & 3.5 & 1.242 & 33 & 1.4 & 0.515 \\
\hline $\mathrm{Mg}$ & $\mathrm{mg} \mathrm{L}^{-1}$ & 21 & 1.6 & 0.850 & 9 & 1.2 & 0.531 & 33 & 0.5 & 0.191 \\
\hline $\mathrm{Na}$ & $\mathrm{mg} \mathrm{L}^{-1}$ & 21 & 13.0 & 1.493 & 9 & 10.7 & 7.918 & 33 & 2.7 & 2.584 \\
\hline $\mathrm{Fe}$ & $\mathrm{mg} \mathrm{L}^{-1}$ & 21 & 0.2 & 0.107 & 9 & 0.3 & 0.153 & 33 & 0.1 & 0.030 \\
\hline $\mathrm{Zn}$ & $\mu \mathrm{g} \mathrm{L}^{-1}$ & 21 & 44.5 & 11.346 & 9 & 101.2 & 23.963 & 33 & 32.2 & 12.535 \\
\hline $\mathrm{Ni}$ & $\mu \mathrm{g} \mathrm{L}^{-1}$ & 21 & 0.5 & 0.031 & 9 & 0.8 & 0.099 & 33 & 0.5 & 0.105 \\
\hline $\mathrm{Cr}$ & $\mu \mathrm{g} \mathrm{L}^{-1}$ & 21 & 0.3 & 0.103 & 9 & 0.6 & 0.134 & 33 & 0.3 & 0.003 \\
\hline $\mathrm{Mn}$ & $\mu \mathrm{g} \mathrm{L}^{-1}$ & 21 & 16.8 & 10.454 & 9 & 18.7 & 2.633 & 33 & 7.1 & 1.980 \\
\hline $\mathrm{K}$ & $\mathrm{mg} \mathrm{L}^{-1}$ & 21 & 0.8 & 0.643 & 9 & 0.3 & 0.133 & 33 & 0.2 & 0.010 \\
\hline Co & $\mu \mathrm{g} \mathrm{L}^{-1}$ & 21 & 0.2 & 0.025 & 9 & 0.2 & 0.021 & 33 & 0.2 & 0.004 \\
\hline $\mathrm{Li}$ & $\mu \mathrm{g} \mathrm{L}^{-1}$ & 21 & 0.2 & 0.033 & 9 & 0.2 & 0.058 & 33 & 0.1 & 0.020 \\
\hline $\mathrm{Sr}$ & $\mu \mathrm{g} \mathrm{L}^{-1}$ & 21 & 7.3 & 2.304 & 9 & 6.3 & 1.148 & 33 & 3.1 & 1.118 \\
\hline $\mathrm{Ti}$ & $\mu \mathrm{g} \mathrm{L}^{-1}$ & 21 & 2.6 & 0.922 & 9 & 3.8 & 0.994 & 33 & 1.1 & 0.605 \\
\hline $\mathrm{Ba}$ & $\mu \mathrm{g} \mathrm{L}^{-1}$ & 21 & 8.5 & 2.194 & 9 & 20.2 & 6.738 & 33 & 6.7 & 3.064 \\
\hline $\mathrm{Al}$ & $\mathrm{mg} \mathrm{L}^{-1}$ & 21 & 0.1 & 0.015 & 9 & 0.1 & 0.014 & 33 & 0.0 & 0.011 \\
\hline $\mathrm{P}$ & $\mathrm{mg} \mathrm{L}^{-1}$ & 21 & 0.0 & 0.009 & 9 & 0.0 & 0.021 & 33 & 0.0 & 0.005 \\
\hline
\end{tabular}




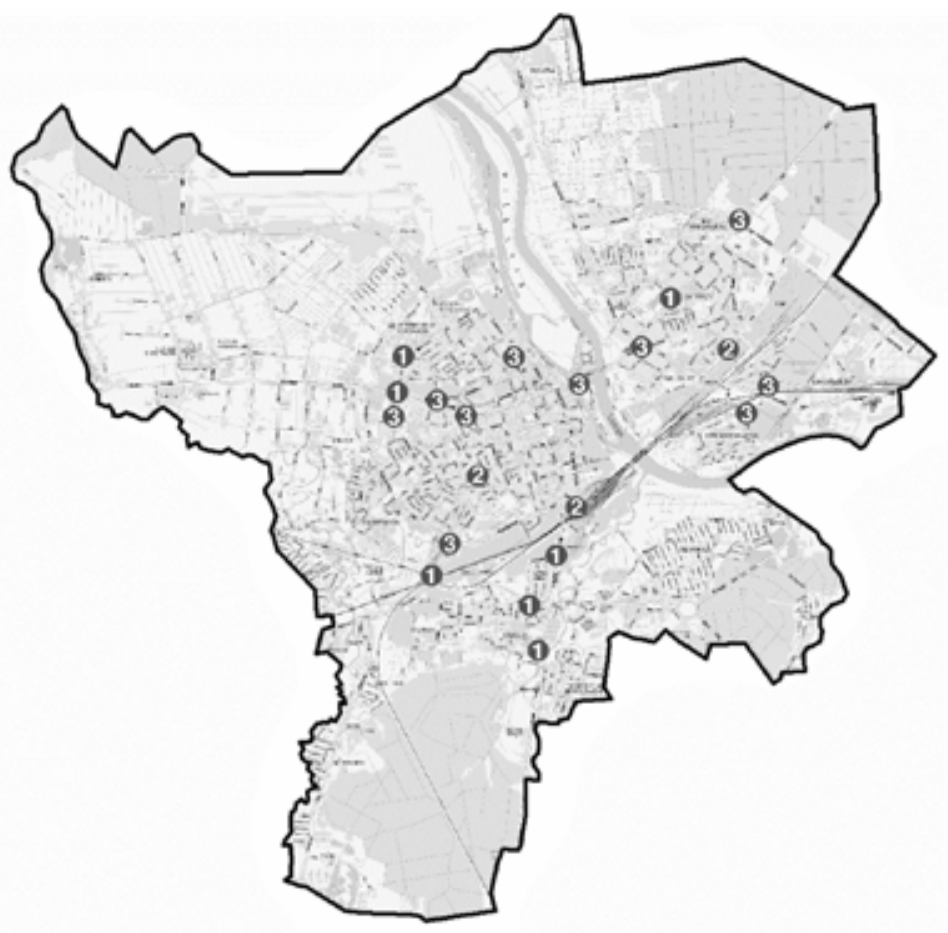

Figure 2. Spatial distribution of cluster analysis of snow samples taken in January.

The second cluster includes three sampling plots close to railway and industrial area. This cluster characterises with relatively low concentrations of $\mathrm{Ca}, \mathrm{Mg}, \mathrm{Na}, \mathrm{K}, \mathrm{Co}, \mathrm{Li}, \mathrm{Sr}, \mathrm{Al}$, P. The concentrations of $\mathrm{Cu}\left(28.7 \pm 4.22 \mu \mathrm{g} \mathrm{L}^{-1}\right) ; \mathrm{Pb}\left(7.3 \pm 0.85 \mu \mathrm{g} \mathrm{L}^{-1}\right) ; \mathrm{Fe}$ $\left(0.3 \pm 1.5 \mathrm{mg} \mathrm{L}^{-1}\right) ; \mathrm{Zn}(101.2 \pm 23.96 \mu \mathrm{g} \mathrm{L}-1) ; \mathrm{Ni}(0.8$ $\left.\pm 0.1 \mu \mathrm{g} \mathrm{L}^{-1}\right) ; \mathrm{Cr}\left(0.8 \pm 0.1 \mu \mathrm{g} \mathrm{L}^{-1}\right) ; \operatorname{Mn}(18.7 \pm 2.6 \mu \mathrm{g}$ $\left.\mathrm{L}^{-1}\right) ; \operatorname{Ti}\left(3.8 \pm 0.99 \mu \mathrm{g} \mathrm{L}^{-1}\right) ; \mathrm{Ba}\left(20.2 \pm 6.74 \mu \mathrm{g} \mathrm{L}^{-1}\right)$ are higher than the first and third cluster and significantly higher than in natural areas (Shevchenko, 2016). The higher concentrations of $\mathrm{Cu}, \mathrm{Pb}, \mathrm{Fe}, \mathrm{Zn}, \mathrm{Ni}, \mathrm{Cr}, \mathrm{Mn}$ are associated with fossil and oil combustion (Pacyna \& Pacyna, 2001).
The third cluster represents relatively clean areas with low concentrations of all trace elements. The snow sample plots classified in the third cluster are mostly open areas with some green infrastructure. The spatial distribution of clusters is presented in Figure 2.

Snow samples were collected in February and the content of 26 trace elements has been analysed using ICP-OES. The concentrations of $\mathrm{Cd}, \mathrm{Cu}, \mathrm{Pb}$, $\mathrm{Ca}, \mathrm{Mg}, \mathrm{Na}, \mathrm{Fe}, \mathrm{Zn}, \mathrm{Ni}, \mathrm{Cr}, \mathrm{Mn}, \mathrm{K}, \mathrm{As}, \mathrm{Co}, \mathrm{Li}, \mathrm{Sr}$, $\mathrm{Ti}, \mathrm{Tl}, \mathrm{Ba}, \mathrm{V}, \mathrm{Al}, \mathrm{P}, \mathrm{Sb}$ were different among samples and other elements' concentrations were smaller than instrument error, and they were excluded from further analysis. Snow samples taken in February average

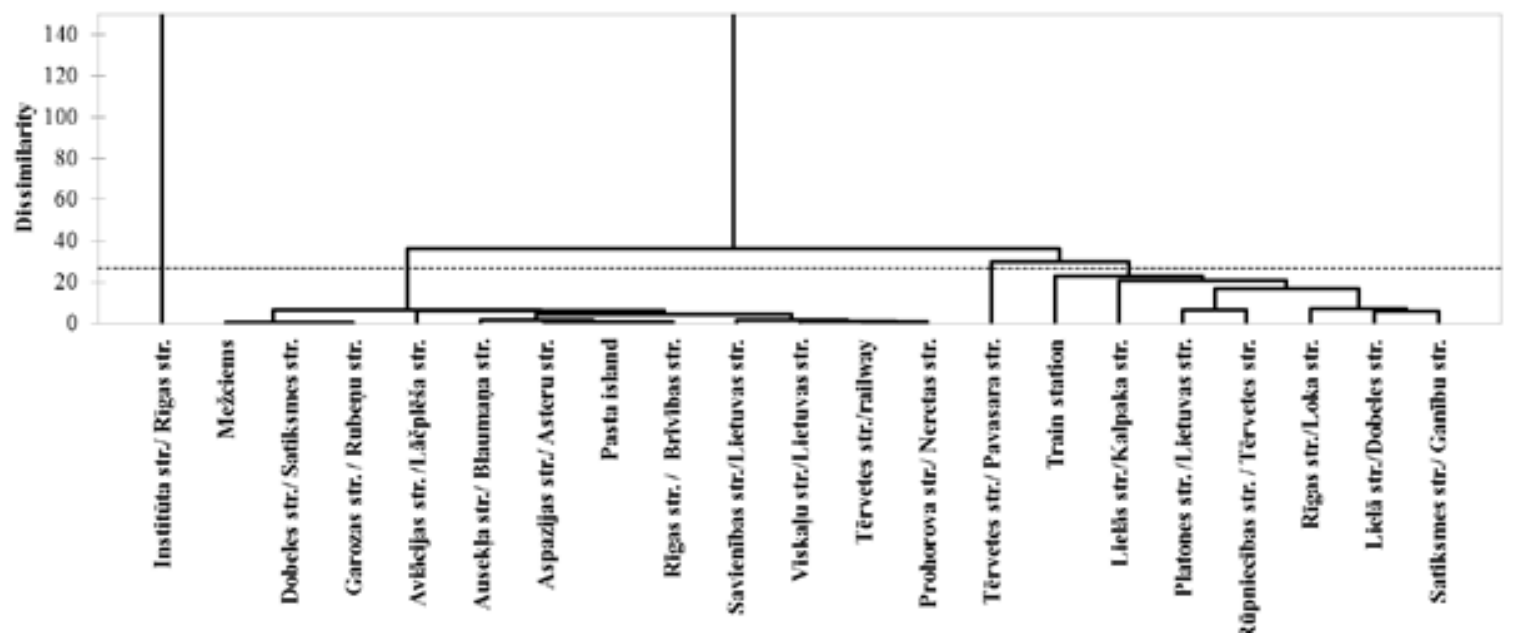

Figure 3. Dendogram of cluster analysis of snow samples taken in February. 
Table 3

The mean ad standard deviation of trace elements by cluster for snow samples taken in February

\begin{tabular}{|c|c|c|c|c|c|c|c|c|c|c|c|c|c|}
\hline \multirow[b]{2}{*}{ 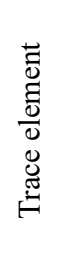 } & \multirow[b]{2}{*}{ 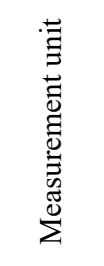 } & \multicolumn{3}{|c|}{$1^{\text {st }}$ cluster } & \multicolumn{3}{|c|}{$2^{\text {nd }}$ cluster } & \multicolumn{3}{|c|}{$3^{\text {rd }}$ cluster } & \multicolumn{3}{|c|}{$4^{\text {th }}$ cluster } \\
\hline & & $\begin{array}{l}\tilde{0} \\
\dot{0} \\
\dot{0} \\
\dot{0} \\
\dot{z} \\
0 \\
0 \\
0 \\
0\end{array}$ & $\stackrel{\varpi}{\Xi ँ}^{\stackrel{\Xi}{\Sigma}}$ & 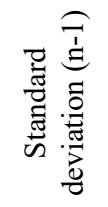 & 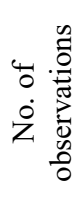 & 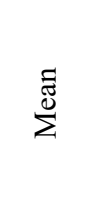 & 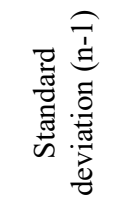 &  & $\stackrel{\mathbb{E}}{\Sigma}^{\mathbb{E}}$ & 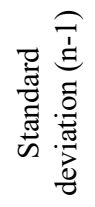 & 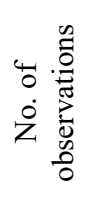 & $\stackrel{\Xi}{\Xi_{\Sigma}^{\varpi}}$ & 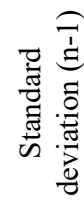 \\
\hline $\mathrm{Cd}$ & $\mu \mathrm{g} \mathrm{L}^{-1}$ & 36 & 0.2 & 0.000 & 21 & 0.2 & 0.055 & 3 & 0.2 & 0.185 & 3 & 0.4 & 0.185 \\
\hline $\mathrm{Cu}$ & $\mu \mathrm{g} \mathrm{L}^{-1}$ & 36 & 15.5 & 16.141 & 21 & 29.9 & 13.677 & 3 & 10.4 & 0.625 & 3 & 150.4 & 0.625 \\
\hline $\mathrm{Pb}$ & $\mu \mathrm{g} \mathrm{L}^{-1}$ & 36 & 6.0 & 3.093 & 21 & 15.6 & 6.327 & 3 & 24.3 & 0.780 & 3 & 31.9 & 0.780 \\
\hline $\mathrm{Ca}$ & $\mathrm{mg} \mathrm{L}^{-1}$ & 36 & 23.0 & 13.693 & 21 & 45.1 & 34.135 & 3 & 14.4 & 0.025 & 3 & 259.6 & 0.025 \\
\hline $\mathrm{Mg}$ & $m g L^{-1}$ & 36 & 9.0 & 5.534 & 21 & 18.3 & 13.952 & 3 & 5.7 & 0.002 & 3 & 118.5 & 0.002 \\
\hline $\mathrm{Na}$ & $\mathrm{mg} \mathrm{L}^{-1}$ & 36 & 9.1 & 9.558 & 21 & 17.4 & 23.954 & 3 & 41.6 & 0.024 & 3 & 20.2 & 0.024 \\
\hline $\mathrm{Fe}$ & $\mathrm{mg} \mathrm{L}^{-1}$ & 36 & 1.1 & 0.588 & 21 & 2.7 & 1.523 & 3 & 0.4 & 0.003 & 3 & 14.6 & 0.003 \\
\hline $\mathrm{Zn}$ & $\mu \mathrm{g} \mathrm{L}^{-1}$ & 36 & 76.5 & 39.684 & 21 & 204.5 & 179.944 & 3 & 125.9 & 1.189 & 3 & 680.6 & 1.189 \\
\hline $\mathrm{Ni}$ & $\mu \mathrm{g} \mathrm{L}^{-1}$ & 36 & 1.4 & 0.570 & 21 & 3.1 & 1.367 & 3 & 0.9 & 0.309 & 3 & 11.8 & 0.309 \\
\hline $\mathrm{Cr}$ & $\mu \mathrm{g} \mathrm{L}^{-1}$ & 36 & 1.3 & 0.626 & 21 & 4.1 & 2.128 & 3 & 1.2 & 0.280 & 3 & 14.0 & 0.280 \\
\hline $\mathrm{Mn}$ & $\mu \mathrm{g} \mathrm{L}^{-1}$ & 36 & 97.7 & 51.036 & 21 & 178.8 & 87.448 & 3 & 62.8 & 0.099 & 3 & 983.6 & 0.099 \\
\hline $\mathrm{K}$ & $m g L^{-1}$ & 36 & 0.5 & 0.325 & 21 & 0.6 & 0.140 & 3 & 1.9 & 0.059 & 3 & 1.6 & 0.059 \\
\hline As & $\mu \mathrm{g} \mathrm{L}^{-1}$ & 36 & 1.9 & 0.000 & 21 & 2.1 & 0.201 & 3 & 1.9 & 1.912 & 3 & 3.5 & 1.912 \\
\hline $\mathrm{Co}$ & $\mu \mathrm{g} \mathrm{L}^{-1}$ & 36 & 0.7 & 0.262 & 21 & 1.2 & 0.415 & 3 & 0.4 & 0.216 & 3 & 7.5 & 0.216 \\
\hline $\mathrm{Li}$ & $\mu \mathrm{g} \mathrm{L}^{-1}$ & 36 & 0.7 & 0.331 & 21 & 1.4 & 0.840 & 3 & 0.4 & 0.021 & 3 & 9.6 & 0.021 \\
\hline $\mathrm{Sr}$ & $\mu \mathrm{g} \mathrm{L}^{-1}$ & 36 & 18.4 & 9.445 & 21 & 38.4 & 20.600 & 3 & 29.5 & 0.104 & 3 & 173.5 & 0.104 \\
\hline $\mathrm{Ti}$ & $\mu \mathrm{g} \mathrm{L}^{-1}$ & 36 & 16.4 & 7.802 & 21 & 27.9 & 8.458 & 3 & 4.9 & 0.071 & 3 & 192.0 & 0.071 \\
\hline $\mathrm{Tl}$ & $\mu \mathrm{g} \mathrm{L}^{-1}$ & 36 & 0.8 & 0.000 & 21 & 0.8 & 0.006 & 3 & 0.8 & 0.804 & 3 & 0.8 & 0.804 \\
\hline $\mathrm{Ba}$ & $\mu \mathrm{g} \mathrm{L}^{-1}$ & 36 & 27.4 & 20.499 & 21 & 87.7 & 83.590 & 3 & 32.0 & 0.581 & 3 & 222.1 & 0.581 \\
\hline $\mathrm{V}$ & $\mu \mathrm{g} \mathrm{L}^{-1}$ & 36 & 1.3 & 0.562 & 21 & 2.7 & 0.757 & 3 & 0.7 & 0.394 & 3 & 13.5 & 0.394 \\
\hline $\mathrm{Al}$ & $\mathrm{mg} \mathrm{L}^{-1}$ & 36 & 0.4 & 0.174 & 21 & 0.8 & 0.332 & 3 & 0.3 & 0.001 & 3 & 4.0 & 0.001 \\
\hline$P$ & $\mathrm{mg} \mathrm{L}^{-1}$ & 36 & 0.1 & 0.079 & 21 & 0.3 & 0.064 & 3 & 1.9 & 0.003 & 3 & 1.2 & 0.003 \\
\hline $\mathrm{Sb}$ & $\mu \mathrm{g} \mathrm{L}^{-1}$ & 36 & 1.3 & 0.030 & 21 & 1.7 & 0.402 & 3 & 1.3 & 1.330 & 3 & 3.5 & 1.330 \\
\hline
\end{tabular}

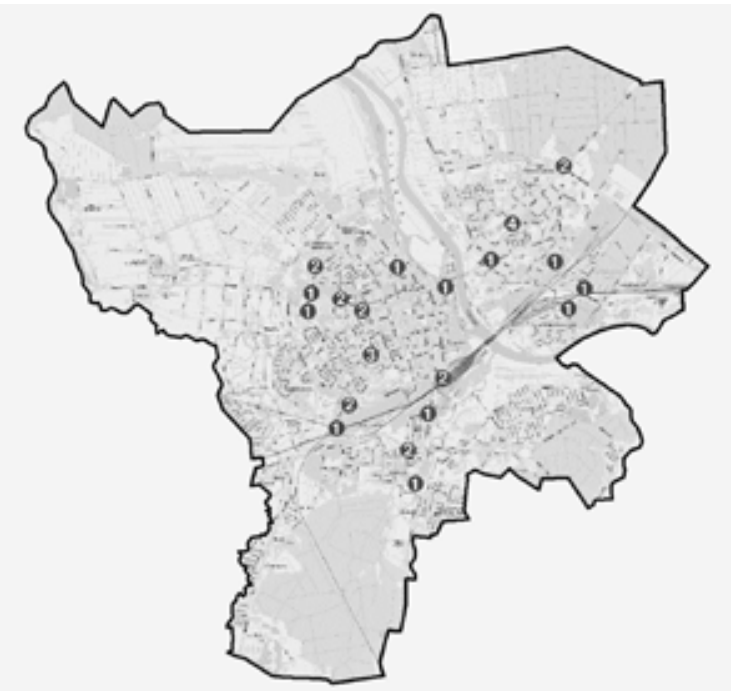

Figure 4. Spatial distribution of cluster analysis of snow samples taken in February. 
trace elements concentration data cluster dendogram is presented in Figure 3.

The clustering results are quite different from January clusters, and it is related to extremely high traffic during snow exposition period. The February data are characterised with much higher concentrations of trace elements. The first cluster represents relatively clean areas and all trace elements concentrations are lower than for other clusters (see Table 3 ). The second cluster represents areas close to main streets; however, the third and fourth clusters consist of one sampling area.

Results show changes of snow contamination with metals affected by atmospheric deposition. Despite similar snow exposition time during winter period traffic and pyrogenic dust and aerosols reaches snow cover. These data strongly correlates with cultural and art events in the city providing increased traffic intensity and therefore emissions from transport.

\section{Conclusions}

The cluster analysis of snow samples taken in January and February show different cluster spatial and temporal distribution.

The February data clustering results show high anthropogenic impact related with fossil and oil combustion.

The future research has to concentrate on multidimensional analysis of point source and nonpoint source pollution impact on heavy metal spatial and temporal distribution in urban areas.

\section{References}

1. Barbante, C., Jacopo Gabrieli, J., Gabrielli, P., Vallelonga, P.T., Cozzi, G., Turetta, C., Hong, S., Rosman, K., Boutron, C., \& Cescon, P. (2011). A historical record of heavy metal pollution in Alpine snow and ice. Berlin: Persistent Pollution - Past, Present and Future.

2. Tchounwou, P.B., Yedjou, C.G., Patlolla, A.K., \& Sutton, D.Y. (2014). Heavy Metals Toxicity and the Environment. HHS Public Access. Author manuscript. EXS. 2012; 101: 133 - 164.

3. Candelone, J.P., Jaffrezo, J.L., Hong, S., Davidson, C.I., \& Boutron, C.F. (1996). Seasonal variations in heavy metals' concentrations in present day Greenland snow. Science of the Total Environment. Volume 193, Issue 2, pp. $101-110$.

4. Gabrielli, P., Barbante, C., Boutron, C.F., Cozzi, G., Gaspari, V., Planchon, F., Ferrari, C., \& Cescon, P. (2005). Variations in atmospheric trace elements in Dome C (East Antarctica) ice over the last two climatic cycles Atmos. Environ, 39 pp. 6420 - 6429.

5. Barbante, C., Boutron, C.F., Morel, C., Ferrari, C., Jaffrezo, J.L., Cozzi, G., Gaspari, V., \& Cescon, P., (2003). Seasonal variations of heavy metals in central Greenland snow deposited from 1991 to 1995 . J. Environ. Monitor, 5, pp. 328 - 335.

6. Shotyk, W., Zheng, J., Krachler, M., Zdanowicz, C.R.M., \& Koerner, D. (2005). Fischer Predominance of industrial $\mathrm{Pb}$ in recent snow (1994 - 2004) and ice (1842 - 1996) from Devon Island, Arctic Canada Geophys. Res. Lett., 32, p. L21814, DOI: 21810.21029/22005GL02386.

7. Correia, A., Freydier, R., Delmas, R.F., Simoes, J.C., Taupin, J.D., Dupré, B., \& Artaxo, P., (2003). Trace elements in South America aerosol during 20th century inferred from a Nevado Illimani ice core, Eastern Bolivian Andes (6350 m asl) Atmos. Chem. Phys., 3, pp. 1337 - 1352.

8. Van de Velde, K., Boutron, C.F., Ferrari, C., Moreau, A.L., Delmas, R.F., Barbante, C., Bellomi, T., Capodaglio, G., \& Cescon, P. (2000). A two hundred years record of atmospheric cadmium, copper and zinc concentrations in high altitude snow and ice from the French-Italian Alps Geophys. Res. Lett., 27, pp. $249-252$.

9. Schwikowski, M., Barbante, C., Doering, T., Gaeggeler, H.W., Boutron, C.F., Schotterer, U., Tobler, L., Van de Velde, K., Ferrari, C., Cozzi, G., Rosman, K., \& Cescon, P. (2004). Post-17-century changes of European lead emissions recorded in high-altitude alpine snow and ice Environ. Sci. Technol., 38, pp. $957-964$.

10. Dossi, C., Ciceri, E., Giussani, B., Pozzi, A., Galgaro, A., Viero, A., \& Viagano, A. (2007).Water and snow chemistry of main ions and trace elements in the Karst system of Monte Pelmo massif (Dolomites, Eastern Alps, Italy). Marine and Freshwater Research, 58, 649-656.

11. Engelhard, C., De Toffol, S., Lek, I., Rauch, W., \& Dallinger, R. (2007). Environmental impacts of urban management - the alpine case study of Innsbruck. Science of the Total Environment, 32, 286 - 294.

12. Shevchenko, V.P., Pokrovsky, O.S., Vorobyev, S.N., Krickov, I.V., Manasypov, R.M., Politova, N.V., Kopysov, S.G., Dara, O.M., Auda, Y., Shirokova, L.S., Kolesnichenko, L.G., Zemtsov, V.A., \& Kirpotin, S.N. (2016). Impact of snow deposition on major and trace element concentrations and fluxes in surface waters of Western Siberian Lowland. Hydrol. Earth Syst. Sci. Discuss DOI: 10.5194/hess-2016-578, in review. 
13. Loranger, S., Tétrault, M., Kennedy, G., \& Zayed, J. (1996). Manganese and other trace elements in urban snow near an expressway. Environmental Pollution, 92(2), 203 - 211. DOI: 10.1016/0269-7491(95)000828.

14. Moreno, T., Querol, X., Alastuey, A., Reche, C., Cusack, M., Amato, F., \& Gibbons, W. (2011). Variations in time and space of trace metal aerosol concentrations in urban areas and their surroundings. Atmospheric Chemistry and Physics, 11(17), 9415 - 9430. DOI: 10.5194/acp-11-9415-2011.

15. Pacyna, E.G., Pacyna, J.M., \& Pirrone, N. (2001). European emissions of atmospheric mercury from anthropogenic sources in 1995. Atmospheric Environment, 35(17), 2987 - 2996. DOI: 10.1016/S13522310(01)00102-9.

16. Vasić, M.V., Mihailović, A., Kozmidis-Luburić, U., Nemes, T., Ninkov, J., Zeremski-Škorić, T., \& Antić, B. (2012). Metal contamination of short-term snow cover near urban crossroads: Correlation analysis of metal content and fine particles distribution. Chemosphere, 86(6), 585 - 592. DOI: 10.1016/j. chemosphere.2011.10.023. 